\title{
Bayesian genetic parameters for body weight and survival of Nile tilapia farmed in Brazil
}

\author{
Alexandra Inês Santos ${ }^{(1)}$, Ricardo Pereira Ribeiro(1), Lauro Vargas ${ }^{(1)}$, Freddy Mora ${ }^{(2)}$, Luiz Alexandre Filho(1), \\ Darci Carlos Fornari( ${ }^{(1)}$ and Sheila Nogueira de Oliveira ${ }^{(1)}$
}

\begin{abstract}
(1)Universidade Estadual de Maringá, Departamento de Zootecnia, Avenida Colombo, no 5.790, Bloco J45, CEP 87020-900 Maringá, PR, Brazil. E-mail: alexandrainess@gmail.com, rpribeiro@uem.br, Ivargas@uem.br, lafilho@uem.br, drfornari@hotmail.com, she_uem@hotmail.com (2)Universidad de Concepción, Facultad de Ciencias Forestales, Victoria 631, Barrio Universitario, Concepción, Chile. E-mail: freddymora@udec.cl
\end{abstract}

\begin{abstract}
The objective of this study was to estimate genetic parameters for survival and weight of Nile tilapia (Oreochromis niloticus), farmed in cages and ponds in Brazil, and to predict genetic gain under different scenarios. Survival was recorded as a binary response (dead or alive), during harvest time in the 2008 grow-out period. Genetic parameters were estimated using a Bayesian mixed linear-threshold animal model via Gibbs sampling. The breeding population consisted of 2,912 individual fish, which were analyzed together with the pedigree of 5,394 fish. The heritabilities estimates, with $95 \%$ posterior credible intervals, for tagging weight, harvest weight and survival were $0.17(0.09-0.27), 0.21(0.12-0.32)$ and $0.32(0.22-0.44)$, respectively. Credible intervals show a $95 \%$ probability that the true genetic correlations were in a favourable direction. The selection for weight has a positive impact on survival. Estimated genetic gain was high when selecting for harvest weight (5.07\%), and indirect gain for tagging weight $(2.17 \%)$ and survival $(2.03 \%)$ were also considerable.

Index terms: Oreochromis niloticus, correlation, fish genetic improvement, Gibbs sampling, GIFT strain, heritability.

\section{Parâmetros genéticos bayesianos para peso corporal e sobrevivência de tilápias-do-nilo cultivadas no Brasil}

Resumo - O objetivo deste trabalho foi estimar parâmetros genéticos para a sobrevivência e peso de tilápias-do-nilo (Oreochromis niloticus), cultivadas em tanques-rede e viveiro de terra no Brasil, e predizer o ganho genético sob diferentes cenários. Mediu-se a sobrevivência como uma característica binária (peixe vivo ou morto), no período de crescimento de 2008 até a despesca. Os paramêtros genéticos foram estimados pelo modelo animal limiar-linear em análise bayesiana, pela amostragem de Gibbs. A população avaliada foi de 2.912 peixes individuais, que foram analisados juntamente com o pedigree de 5.394 peixes. As herdabilidades, com intervalos de credibilidade de $95 \%$, obtidas para peso à identificação, peso à despesca e sobrevivência foram $0,17(0,09-0,27), 0,21(0,12-0,32)$ e 0,32 $(0,22-0,44)$, respectivamente. Intervalos de credibilidade mostram $95 \%$ de probabilidade de que as verdadeiras correlações genéticas estejam em uma direção favorável. A seleção para peso tem impacto positivo na sobrevivência. O ganho genético estimado foi alto para a seleção quanto ao peso à despesca $(5,07 \%)$, e o ganho indireto para o peso à identificação $(2,17 \%)$ e à sobrevivência $(2,03 \%)$ também foram consideráveis.

Termos para indexação: Oreochromis niloticus, correlação, melhoramento genético de peixes, amostragem de Gibbs, linhagem GIFT, herdabilidade.

\section{Introduction}

Tilapia has become a popular meal around the world (Cressey, 2009; Food and Agriculture Organization of the United Nations, 2009). Systematic efforts to improve tilapia yields and to develop the sustainability of this food sector will be of critical importance to developing countries. In Brazil, a key aspect to maximize productivity in tilapia farming has been to select strains that respond well to specific environmental conditions
(Wagner et al., 2004), with higher productivity and survival per unit of area.

Genetic selection, using quantitative and statistical methods, is responsible for increases in productivity of traditional livestock and crop species. The correct identification of genetically superior individuals is, therefore, crucial and requires knowledge about the genetic control of the traits under selection. Parameters, such as heritability, have been widely investigated for production traits in tilapia (Eknath \& Acosta, 1998; 
Ponzoni et al., 2005; Rutten et al., 2005; Charo-Karisa et al., 2006; Khaw et al., 2008). Mortality rate is also an important trait, and it can have direct implications on farm productivity. The survival of tilapia is affected by a great variety of factors, such as age (Wagner et al., 2004), cultivation density and water quality (Yi \& Lin, 2001), and temperature and diet (Atwood et al., 2003). Few experiments have been carried out to study the genetic control of survival in tilapia (Chiayvareesajja et al., 1999; Charo-Karisa et al., 2006; Rezk et al., 2009).

In Brazil, the interest in fish genetic improvement has been growing, but there are still no studies, reported in literature, on the genetic parameters for traits in fish cultured under the country's agro-climatic conditions. Fish genetic improvement has initiated recently in Southern Brazil, with a wide range of genetic material of Nile tilapia (Eknath \& Acosta, 1998; Ponzoni et al., 2005; Khaw et al., 2008). Since the effectiveness of selection relies on accurate parameter estimates, and heritabilities and genetic correlations can change through time and space (Vehviläinen et al., 2008), it is important to have estimates that are directly relevant to the data of interest (Ponzoni et al., 2005).

Single-trait analyses can be used to obtain first estimates. However, multiple-trait analyses should be favoured, since they allow the estimation of correlations between traits, which can improve the prediction accuracy of the genetic merit of the traits involved. Bayesian inference can also be used in the analyses to add measurement uncertainty to the estimates, as the marginal posterior densities take into account imprecision and show the accuracy of the estimates. The Bayesian methods have been recently introduced in animal breeding. According to Wright et al. (2000), this approach is important to genetic evaluation because it considers the existing variability in model parameters and the prediction values of genetic effects.

The objective of this study was to estimate genetic parameters for survival and weight of Nile tilapia (Oreochromis niloticus), farmed in cages and ponds in Brazil, and to predict genetic gain under different scenarios.

\section{Materials and Methods}

The breeding population used in this study consisted of 33 families of the genetically improved farmed tilapia (GIFT) strain, descendants of fish from the WorldFish Center breeding population of Malaysia.

Part of the experiment was carried out at the Estação de Aquacultura of the Universidade Estadual de Maringá, state of Paraná, Brazil $\left(23^{\circ} 31^{\prime} \mathrm{S}\right.$ and $\left.52^{\circ} 2^{\prime} \mathrm{W}\right)$. The water temperature of the pond ranged from 13 to $30^{\circ} \mathrm{C}$. Another part of the experiment took place in the Rosana hydroelectric power plant reservoir $\left(22^{\circ} 36^{\prime} \mathrm{S}\right.$ and $52^{\circ} 50^{\prime} \mathrm{W}$ ), also in Paraná, in which the fish were farmed in cages. Throughout the experiment, the water temperature in the reservoir ranged from 17 to $28^{\circ} \mathrm{C}$.

The first generation was obtained from two spawning seasons. In the first season, the single pair mating design was used. Some of the mating pairs were repeated in the subsequent season, with the nested mating design (each male breeder was mated with two female breeders), to produce more animals with paternal half-sib families (Ponzoni et al., 2005). This same design was used in the spawning season of 2007, to obtain the progeny of the second generation.

For reproduction, female breeders were individually placed in mating hapas $\left(1 \mathrm{~m}^{3}\right)$, checked for readiness to spawn, and mated to a male. Twice a week, hapas were checked for spawning occurrence. The method of natural incubation was used, and the spawning date was considered the day in which the dam had eggs in its mouth. The sire was transferred to the adjacent hapa of the un-spawned dam in order to produce the paternal half-sibs. Fry were collected after yolk absorption, in the free-swimming stage. Not all males were able to successfully mate with more than one female, and the product of some spawn were lost before fry collection, possibly due to stressed females, which swallowed or rejected the eggs.

The progeny collected from the same mated pair were counted and transferred to four replicate nursing hapas suspended in different locations of the same earthen pond, at a stocking density of 100 pieces per square meter. Two weeks later, the number of fry was reduced to 50 pieces per square meter. In the nursery stage, the fish were given a starter feed with $32 \%$ protein content, twice a day. When the fish reached an average weight of $35 \mathrm{~g}, 88$ progeny from each full-sib family were individually weighed, measured and tagged with implanted microchips. The fish were kept in the nursering hapas during one week for recovery, and identification was re-checked to replace fish which had died or lost its tag. 
Tagged fish from the same nursing hapa were divided into four groups, which were stocked in three cages $\left(4-6 \mathrm{~m}^{3}\right)$ and one earthen pond $\left(140 \mathrm{~m}^{2}\right)$, for the grow-out period. In the cages, the initial stocking density was 24-34 fish per square meter, and 3.4 fish per square meter in the pond. Throughout the grow-out period, feed was provided twice a day, with an amount equivalent to $3-5 \%$ of the live fish weight. The main diet of the experiment was a dry pelleted feed, with $28 \%$ crude protein; the exeception was one cage with a $32 \%$ protein diet. All fish were harvested after five months in communal grow-out. Although farming conditions varied, evidencing different test environments, genotype $\mathrm{x}$ environment interaction was not assessed in this research.

Individual performance data were collected for tagging weight, harvest weight and survival, after a culture period of 150 days, in the 2008 grow-out period, from March to August. Together with the evaluated traits, all relevant information, such as sex, date of spawning, grow-out environment, diet and date of harvest were individually recorded. Age at harvest was calculated from spawning and harvesting dates. Complete records from 2,912 individuals were available for analysis, and were analyzed with complete pedigree data from 5,394 fish, which were included in the relationship matrix. From tagging to the end of the grow-out period, weight traits were recorded in grams and survival was measured as a binary response, with two possible biological events: fish survived and fish not present, including possiblitity of tag loss. The survival variable response has a Bernoulli distribution, with two possible values: 0 and 1 , in which 0 corresponds to the assigned value for a dead fish and 1 for a live fish (Rezk et al., 2009). It is important to highlight that the natural distribution of the data was considered for all the traits in the analyses.

The data were first examined to determine the statistical models to be fitted. Significant effects to be included in the final analysis were identified using MIXED procedure for weight traits, and \%GLIMMIX macro (Bernoulli distribution and logit canonical link function) for survival (SAS Institute, 2005). Type 3 tests of fixed effects were fitted to sex, test environment, and age; and Akaike's information criteria was used to test the random effects of sire, dam (nested within sire) and hapa (nested within sire and dam). Results were confirmed by Bayesian inference, using Winbugs
Software (Spiegelhalter et al., 2003). The fixed effects and the hapa random effect were later included in the final animal model, used for the genetic analysis.

In the genetic analysis, single-trait linear models were fitted to tagging and harvest weights, and a threshold model was fitted to survival. Since production (tagging and harvest weights) and survival traits were individually recorded for all fish, a direct estimation of the genetic association between survival and production traits was possible. To estimate the genetic correlations, the three variables were also analysed with a multiple-trait approach, using a mixed linear-threshold model.

The estimation of genetic parameters and prediction of breeding values was performed with mixed animal models, including the additive genetic effects (a, breeding values) and the maternal common environment effects (c, hapa effect). In the models, the y vector of observed response variable(s) became $\eta$, the continuous latent underlying normally distributed random variable (liability), which corresponds to survival and directly to the observed random variable $(\eta=y)$, for tagging and harvest weights. In matrix notation, the general model refers to:

$$
\eta=X \beta+Z a+W c+\varepsilon,
$$

where $\mathrm{X}, \mathrm{Z}$ and $\mathrm{W}$ are known incidence matrices; $\beta$ is a environmental effect vector (sex, test environment and age); and a, c and $\varepsilon$ are vectors of additive genetic, maternal common environment, and residual random effects, respectively. These vectors were assumed to be multivariate normally distributed, including for survival, in the continuous liability scale, as follows:

$$
\left[\begin{array}{c}
\mathrm{y} \\
\mathrm{a} \\
\mathrm{c} \\
\varepsilon
\end{array}\right] \sim \mathrm{NMV}\left\{\left[\begin{array}{c}
\mathrm{X} \beta \\
0 \\
0 \\
0
\end{array}\right] ;\left[\begin{array}{cccc}
\mathrm{V} & \mathrm{Z}_{1} \mathrm{G} & \mathrm{Z}_{2} \mathrm{G} & \mathrm{R} \\
\mathrm{GZ}_{1}^{\prime} & \mathrm{G} & \phi & \phi \\
\mathrm{CZ}_{2}^{\prime} & \phi & \mathrm{C} & \phi \\
\mathrm{R} & \phi & \phi & \mathrm{R}
\end{array}\right]\right\},
$$

such that $\mathrm{V}=\mathrm{Z}_{1} \mathrm{GZ}_{1}^{\prime}+\mathrm{Z}_{2} \mathrm{CZ}_{2}^{\prime}+\mathrm{R}$.

For single-trait analysis, $\mathrm{G}$ is the (co)variance matrix associated with the random breeding values; $\mathrm{G}=\mathrm{A} \sigma_{\mathrm{a}}^{2}$, in which $\mathrm{A}$ is the matrix of the relationship, and $\sigma_{\mathrm{a}}^{2}$ is the component of additive genetic variance; $\mathrm{C}$ is the maternal common environment (co)variance matrix; $C=I_{m} \sigma_{c}^{2}$, in which $I_{m}$ is an identity matrix, 
with the order of the columns equal to the number of full-sib groups, and $\sigma_{\mathrm{c}}^{2}$ is the variance component, with a combination of the hapa and maternal effect, without genetic structure, and one quarter of the nonadditive genetic effect (common to full-sibs); $\mathrm{R}$ is the residual (co)variance matrix; $R=I_{n} \sigma_{e}^{2}$, in which $I_{n}$ is an identity matrix with the order of the columns equal to the number of observations, and $\sigma_{\mathrm{e}}^{2}$ is the residual variance component.

For multiple-trait analysis,

$$
\begin{aligned}
& \mathrm{G}=\mathrm{G}_{0} \otimes \mathrm{A} \text {, in which } \mathrm{G}_{0}= {\left[\begin{array}{lll}
\sigma_{\mathrm{a}_{1}}^{2} & \sigma_{\mathrm{a}_{1} \mathrm{a}_{2}} & \sigma_{\mathrm{a}_{1} \mathrm{a}_{3}} \\
\sigma_{\mathrm{a}_{1} \mathrm{a}_{2}} & \sigma_{\mathrm{a}_{2}}^{2} & \sigma_{\mathrm{a}_{2} \mathrm{a}_{3}} \\
\sigma_{\mathrm{a}_{1} \mathrm{a}_{3}} & \sigma_{\mathrm{a}_{2} \mathrm{a}_{3}} & \sigma_{\mathrm{a}_{3}}^{2}
\end{array}\right], } \\
& \mathrm{C}=\mathrm{I}_{\mathrm{m}} \otimes \mathrm{C}_{0} \text {, in which } \mathrm{G}_{0}=\left[\begin{array}{lll}
\sigma_{\mathrm{c}_{1}}^{2} & \sigma_{\mathrm{c}_{1} \mathrm{c}_{2}} & \sigma_{\mathrm{c}_{1} \mathrm{c}_{3}} \\
\sigma_{\mathrm{c}_{1} \mathrm{c}_{2}} & \sigma_{\mathrm{c}_{2}}^{2} & \sigma_{c_{2} \mathrm{c}_{3}} \\
\sigma_{\mathrm{c}_{1} \mathrm{c}_{3}} & \sigma_{\mathrm{c}_{2} \mathrm{c}_{3}} & \sigma_{\mathrm{c}_{3}}^{2}
\end{array}\right], \\
& \mathrm{R}=\mathrm{R}_{0} \otimes \mathrm{I}, \text { in which } \mathrm{R}_{0}=\left[\begin{array}{lll}
\sigma_{\mathrm{e}_{1}}^{2} & \sigma_{\mathrm{e}_{1} \mathrm{e}_{2}} & \sigma_{\mathrm{e}_{1} \mathrm{e}_{3}} \\
\sigma_{\mathrm{e}_{1} \mathrm{e}_{2}} & \sigma_{\mathrm{e}_{2}}^{2} & 0 \\
\sigma_{\mathrm{e}_{1} \mathrm{e}_{3}} & 0 & \sigma_{\mathrm{e}_{3}}^{2}
\end{array}\right] .
\end{aligned}
$$

The analyses were done using the Bayesian approach, via Gibbs sampling, which is a variant of the Monte-Carlo Markov chain methods (Mora et al., 2008). The threshold version of the MTGSAM program (Van Tassell et al., 1998) was used to formulate the posterior distribution of each genetic parameter.

Although the program is flexible in relation to the models and analyses which can be used, assumptions for prior distributions are previously defined. A noninformative flat prior distribution is considered for environmental effects, and a normal distribution for random (additive genetic and residual) effects. For the genetic effects, a known (co)variance structure, which corresponds to the numerator relationship matrix, is assumed. The prior distribution used for variance components $\left(\sigma_{\mathrm{a}}^{2}, \sigma_{\mathrm{p}}^{2}\right.$ and $\left.\sigma_{\mathrm{e}}^{2}\right)$ is the inverted gamma distribution $(\Gamma \mathrm{I})$ :

$\sigma_{\mathrm{a}}^{2} \sim \Gamma \mathrm{I}\left(\mathrm{g}_{0}, v_{\mathrm{g}}\right), \sigma_{\mathrm{c}}^{2} \sim \Gamma \mathrm{I}\left(\mathrm{c}_{0}, v_{\mathrm{c}}\right)$ and $\sigma_{\mathrm{e}}^{2} \sim \Gamma \mathrm{I}\left(\mathrm{s}_{0}, v_{\mathrm{e}}\right)$,

and, such that:

$$
\mathrm{f}\left(\sigma_{\mathrm{a}}^{2} \mid \mathrm{g}_{0}, \nu_{\mathrm{g}}\right) \propto\left(\sigma_{\mathrm{a}}^{2}\right)^{-1 / 2(\mathrm{vg}+2)} \cdot \mathrm{e}^{-1 / 2\left(\mathrm{~g}_{0} \sigma_{\mathrm{a}}^{-2}\right)},
$$

$$
\begin{aligned}
& \mathrm{f}\left(\sigma_{\mathrm{c}}^{2} \mid \mathrm{c}_{0}, v_{\mathrm{c}}\right) \propto\left(\sigma_{\mathrm{c}}^{2}\right)^{-1 / 2\left(\mathrm{v}_{\mathrm{c}}+2\right)} \cdot \mathrm{e}^{-1 / 2\left(\mathrm{c}_{0} \sigma_{\mathrm{c}}^{-2}\right)}, \\
& \mathrm{f}\left(\sigma_{\mathrm{e}}^{2} \mid \mathrm{r}_{0}, v_{\mathrm{e}}\right) \propto\left(\sigma_{\mathrm{e}}^{2}\right)^{-1 / 2\left(\mathrm{v}_{\mathrm{e}}+2\right)} \cdot \mathrm{e}^{-1 / 2\left(\mathrm{r}_{0} \sigma_{\mathrm{e}}^{-2}\right)},
\end{aligned}
$$

in which $v_{g}, v_{c}$ e $v_{e}$ are the degrees of freedom of the distributions, equivalent to degrees of belief, regarding the parameters $\sigma_{\mathrm{a}}^{2}, \sigma_{\mathrm{p}}^{2}$ and $\sigma_{\mathrm{e}}^{2} ; \mathrm{g}_{0}, \mathrm{c}_{0}$ and $\mathrm{r}_{0}$ are scale parameters for the distributions of $\sigma_{\mathrm{a}}^{2}, \sigma_{\mathrm{c}}^{2}$ and $\sigma_{\mathrm{e}}^{2}$.

In the multiple-trait case, the inverted wishart distribution (IW) is used to model the variance-covariance matrix $\left(\mathrm{G}_{0}, \mathrm{C}_{0}\right.$ and $\left.\mathrm{R}_{0}\right)$. Therefore, $\mathrm{G}_{0} \sim \mathrm{IW}\left(\mathrm{G}_{*}, \mathrm{v}_{\mathrm{g}}\right), \mathrm{C}_{0}$ $\sim \operatorname{IW}\left(\mathrm{C}_{*}, \mathrm{~V}_{\mathrm{c}}\right)$ and $\mathrm{R}_{0} \sim \operatorname{IW}\left(\mathrm{R}_{*}, \mathrm{~V}_{\mathrm{e}}\right)$ :

$$
\begin{aligned}
& \mathrm{f}\left(\mathrm{G}_{0} \mid \mathrm{G}^{*}, \mathrm{v}_{\mathrm{g}}\right) \propto|\mathrm{G}|^{-1 / 2\left(\mathrm{v}_{\mathrm{g}}+\mathrm{m}_{\mathrm{g}}+1\right)} \cdot \mathrm{e}^{-1 / 2 \operatorname{tr}\left(\mathrm{G}^{*-1} \mathrm{G}^{-1}\right)}, \\
& \mathrm{f}\left(\mathrm{C}_{0} \mid \mathrm{C}^{*}, \mathrm{v}_{\mathrm{c}}\right) \propto|\mathrm{C}|^{-1 / 2\left(\mathrm{v}_{\mathrm{c}}+\mathrm{m}_{\mathrm{c}}+1\right)} \cdot \mathrm{e}^{-1 / 2 \operatorname{tr}\left(\mathrm{C}^{*-1} \mathrm{C}^{-1}\right)}, \\
& \mathrm{f}\left(\mathrm{R}_{0} \mid \mathrm{R}^{*}, \mathrm{v}_{\mathrm{e}}\right) \propto|\mathrm{R}|^{-1 / 2\left(\mathrm{v}_{\mathrm{e}}+\mathrm{m}_{\mathrm{r}}+1\right)} \cdot \mathrm{e}^{-1 / 2 \operatorname{tr}\left(\mathrm{R}^{*-1} \mathrm{R}^{-1}\right)},
\end{aligned}
$$

in which $\mathrm{mg}, \mathrm{m}_{\mathrm{c}}$ and $\mathrm{m}_{\mathrm{r}}$ are the order of the matrices $\mathrm{G}_{0}, \mathrm{C}_{0}$ and $\mathrm{R}_{0}$; and $\mathrm{G}^{*}, \mathrm{C}^{*}$ and $\mathrm{R}^{*}$ are the matrices of the scale parameter of the $\mathrm{G}_{0}, \mathrm{C}_{0}$ e $\mathrm{R}_{0}$ distributions.

To run the Gibbs sampling, it is necessary to define a few parameters of the variance components distribution. Preliminary (single and multiple-trait) analyses using the computer program ASReml (Gilmour et al., 2002) supplied the starting values, and minimum scalar shape parameters (degree of belief) were applied. As recommended for binary data (Van Tassell et al., 1998), residual variance of 1, called standard parameterization, was used for survival, because there was only one threshold.

The joint posterior probability density function of the parameters was obtained by the product of the prior distributions and the likelihood function, as described by Van Tassel et al. (1998). The fully conditional densities for each parameter derive from the joint posterior density and generated the marginal distributions of the parameters of interest, with the Gibbs Sampler algorithm.

Posterior estimates for the heritabilities $\left(h^{2}\right)$ of production and survival traits were calculated from posterior samples of variance components, using the expression: $h^{2}=\sigma_{a}^{2} /\left(\sigma_{a}^{2}+\sigma_{c}^{2}+\sigma_{e}^{2}\right)$, in which $\sigma_{\mathrm{a}}^{2}, \sigma_{\mathrm{c}}^{2}$ and $\sigma_{\mathrm{e}}^{2}$ are the additive genetic, maternal common environment and residual variances.

The maternal common environment effect $\left(c^{2}\right)$ is a result of the separate rearing of the full-sibs, before 
they are large enough to be tagged. Samples of the posterior distributions for this parameter were obtained with: $\mathrm{c}^{2}=\sigma_{\mathrm{c}}^{2} /\left(\sigma_{\mathrm{a}}^{2}+\sigma_{\mathrm{c}}^{2}+\sigma_{\mathrm{e}}^{2}\right)$.

Additive genetic association between each pair of traits, measured in the same fish, was calculated by:

$$
r_{g}=\sigma_{a_{X Y}} / \sqrt{\sigma_{a_{X}}^{2} \times \sigma_{a_{Y}}^{2}},
$$

with $\sigma_{a_{x y}}$ corresponding to posterior distribution samples of additive covariance between each pair of traits, in which $\mathrm{X}$ and $\mathrm{Y}$ are tagging weight, harvest weight or survival; $\sigma_{\mathrm{a}_{\mathrm{x}}}$ and $\sigma_{\mathrm{a}_{\mathrm{y}}}$ are posterior distribution samples of additive genetic variance for the pair of traits in consideration.

Convergence of the Gibbs chain was checked using the Heidelberger \& Welch (1983) test, available at the Coda library of the program R 2.6.2 (R Development Core Team, 2007).

Estimates of posterior means were given by the expected value of the fully conditional distributions for the (co)variance components. Other measures of location and Bayesian credible intervals were also calculated for each parameter. Response to selection for harvest weight and correlated responses for initial weight and survival were estimated using the breeding values (BV) of individual fish, by calculating the predicted genetic gain:

$$
\left(\left(\overline{\mathrm{BV}}_{\text {selected fish }}-\overline{\mathrm{BV}}_{\text {general fish }}\right) / \overline{\mathrm{X}}\right) \times 100 \text {. }
$$

Breeding values on the liability scale were transformed to the phenotypic scale, using: $p_{i}=\Phi\left(\mu+B L_{i}\right)$, in which $p_{i}$ corresponds to the expected category of fish i; $\Phi$, the cumulative probability function of the standard normal distribution; $\mu$, the probit function corresponding to the mean liability of trait; $\mathrm{BVL}_{\mathrm{i}}$, the breeding value estimated on the liability scale for fish, i.

\section{Results and Discussion}

At the end of the experiment, 2,735 fish were harvested, reaching an average body weight of $325.81 \mathrm{~g}$, with a standard deviation of $131.82 \mathrm{~g}$. The survival average in communal testing among the fish families was $90 \%$, which agrees with the high survival rate found for tilapia in the grow-out period (Wagner et al., 2004; Luan et al., 2008; Ponzoni et al., 2008).
These results confirm the adaptability of the strain, and the great potential of this genetic resource in Brazil.

Even though it was not possible to control tag loss throughout the entire experiment, it was considered to be low, if not nil. This conclusion is based on the control done while fish were recovering from tagging, a critical period fish that died were replaced with individuals from the same family. Furthermore fish were tagged at $35 \mathrm{~g}$, considered late for tagging. In experiments (Charo-Karisa et al., 2006; Rezk et al., 2009) carried out to study the genetic control of tilapia survival, tagging was performed when fish were in a smaller size ( 2 to $5 \mathrm{~g}$ ). As a result, survival rates were lower, varying from 35 to $81 \%$. Luan et al. (2008) observed that tagged fish with 12 to $15 \mathrm{~g}$ had a survival rate higher than $90 \%$. Tagging at an earlier period is desirable, because it avoids the accumulation of the common environment effect. Eventhough this was not possible in this study, it assures more appropriate procedures and has accounted for higher survival rates.

The Markov chains achieved convergence for all parameters using a burn-in of 5,000 iterations and a total of 1,005,000 Gibbs sampling rounds; 10,000 samples were retrieved to estimate marginal posterior distributions. To guarantee that the results obtained were sensible, as recommended by Van Tassell et al. (1998), the estimates from preliminary analyses, which supplied the priors (ASReml, logit link function), were also used to check the modal estimates of posterior distributions, which were proven to be consistent (Tables 1 and 2).

The estimates obtained in the single and multiple-trait approaches were similar, though posterior modals were closer than posterior means (Tables 1 and 2). The relative differences among mean, median and mode of the posterior densities were larger for single-trait analyses. However, the differences were small and reflected a tendency of symmetry, which can be confirmed by the marginal posterior distributions of the heritabilities and genetic correlations from the multiple-trait analyses, shown in Figures 1 and 2.

Based on multiple-trait analyses, heritability estimates for tagging weight were lower than those for harvest weight, and were similar to the ones obtained by Bolivar \& Newkirk (2002), Rutten et al. (2005) and by Rezk et al. (2009). The estimates were also lower than those reported by Ponzoni et al. (2005) and 
Table 1. Single-trait estimates of additive genetic $\left(\sigma_{\mathrm{a}}^{2}\right)$, maternal common environment $\left(\sigma_{\mathrm{c}}^{2}\right)$ and residual $\left(\sigma_{\mathrm{e}}^{2}\right)$ variance components, heritabilities $\left(\mathrm{h}^{2}\right)$ and maternal common environment effect $\left(\mathrm{c}^{2}\right)$, with $95 \%$ credible intervals for tagging weight, harvest body weight, and survival rate in tilapia farmed in Brazil.

\begin{tabular}{|c|c|c|c|c|c|c|}
\hline \multirow[t]{2}{*}{ Parameter } & \multirow[t]{2}{*}{ Mean } & \multirow[t]{2}{*}{ Median } & \multirow[t]{2}{*}{ Mode $^{(1)}$} & \multirow[t]{2}{*}{ SD } & \multicolumn{2}{|c|}{ Credible interval (\%) } \\
\hline & & & & & 2.5 & 97.5 \\
\hline & \multicolumn{6}{|c|}{ Tagging weight } \\
\hline$\sigma_{\mathrm{a}}^{2}$ & 117.04 & 113.30 & 108.14 & 45.74 & 48.97 & 199.51 \\
\hline$\sigma_{\mathrm{c}}^{2}$ & 172.61 & 170.47 & 166.67 & 29.42 & 128.19 & 223.77 \\
\hline$\sigma_{\mathrm{e}}^{2}$ & 285.97 & 287.67 & 292.17 & 23.58 & 244.31 & 321.62 \\
\hline$h^{2}$ & 0.20 & 0.20 & 0.18 & 0.07 & 0.09 & 0.33 \\
\hline \multirow[t]{2}{*}{$\mathrm{c}^{2}$} & 0.30 & 0.30 & 0.29 & 0.04 & 0.23 & 0.37 \\
\hline & \multicolumn{6}{|c|}{ Harvest weight } \\
\hline$\sigma_{\mathrm{a}}^{2}$ & $2,216.68$ & $2,156.12$ & $2,079.60$ & 688.83 & $1,204.23$ & $3,453.76$ \\
\hline$\sigma_{\mathrm{c}}^{2}$ & $1,147.64$ & $1,129.30$ & $1,115.22$ & 223.57 & 818.84 & $1,541.52$ \\
\hline$\sigma_{\mathrm{e}}^{2}$ & $5,965.53$ & $5,985.52$ & $6,013.76$ & 384.03 & $5,289.81$ & $6,564.93$ \\
\hline $\mathrm{h}^{2}$ & 0.24 & 0.23 & 0.23 & 0.07 & 0.13 & 0.35 \\
\hline \multirow[t]{2}{*}{$\underline{\mathrm{c}^{2}}$} & 0.12 & 0.12 & 0.12 & 0.02 & 0.09 & 0.16 \\
\hline & \multicolumn{6}{|c|}{ Survival } \\
\hline$\sigma_{\mathrm{a}}^{2}$ & 0.04 & 0.04 & 0.04 & 0.01 & 0.03 & 0.05 \\
\hline$\sigma_{\mathrm{c}}^{2}$ & 0.00 & 0.00 & 0.00 & 0.00 & 0.00 & 0.00 \\
\hline$\sigma_{\mathrm{e}}^{2}$ & 0.06 & 0.06 & 0.06 & 0.01 & 0.05 & 0.06 \\
\hline $\mathrm{h}^{2}$ & 0.40 & 0.40 & 0.33 & 0.08 & 0.33 & 0.55 \\
\hline$c^{2}$ & 0.00 & 0.00 & 0.00 & 0.00 & 0.00 & 0.00 \\
\hline
\end{tabular}

${ }^{(1)}$ Kernel density estimates of the marginal posterior distributions. SD: standard deviation.

Table 2. Multiple-trait estimates of additive genetic $\left(\sigma_{\mathrm{a}}^{2}\right)$, maternal common environment $\left(\sigma_{\mathrm{c}}^{2}\right)$ and residual $\left(\sigma_{\mathrm{e}}^{2}\right)$ variance components, heritabilities $\left(\mathrm{h}^{2}\right)$ and maternal common environment effect $\left(\mathrm{c}^{2}\right)$, with $95 \%$ credible intervals for tagging weight, harvest body weight and survival rate in tilapia farmed in Brazil.

\begin{tabular}{|c|c|c|c|c|c|c|}
\hline \multirow[t]{2}{*}{ Parameter } & \multirow[t]{2}{*}{ Mean } & \multirow[t]{2}{*}{ Median } & \multirow[t]{2}{*}{ Mode $^{(1)}$} & \multirow[t]{2}{*}{ SD } & \multicolumn{2}{|c|}{ Credible interval (\%) } \\
\hline & & & & & 2.5 & 97.5 \\
\hline & \multicolumn{6}{|c|}{ Tagging weight } \\
\hline$\sigma_{\mathrm{a}}^{2}$ & 96.81 & 92.68 & 85.65 & 33.22 & 50.24 & 157.06 \\
\hline$\sigma_{\mathrm{c}}^{2}$ & 180.86 & 179.07 & 176.37 & 27.13 & 139.39 & 228.59 \\
\hline$\sigma_{\mathrm{e}}^{2}$ & 288.39 & 290.07 & 294.26 & 17.85 & 256.63 & 314.76 \\
\hline$h^{2}$ & 0.17 & 0.16 & 0.15 & 0.06 & 0.09 & 0.27 \\
\hline \multirow[t]{2}{*}{$\mathrm{c}^{2}$} & 0.32 & 0.32 & 0.32 & 0.04 & 0.26 & 0.38 \\
\hline & \multicolumn{6}{|c|}{ Harvest weight } \\
\hline$\sigma_{\mathrm{a}}^{2}$ & $2,194.61$ & $2,132.06$ & $2,141.53$ & 707.94 & $1,160.17$ & $3,479.63$ \\
\hline$\sigma_{\mathrm{c}}^{2}$ & $1,171.82$ & $1,152.89$ & $1,127.51$ & 240.16 & 813.20 & $1,592.28$ \\
\hline$\sigma_{\mathrm{e}}^{2}$ & $6,880.10$ & $6,903.07$ & $6,934.89$ & 414.83 & $6,149.30$ & $7,516.86$ \\
\hline $\mathrm{h}^{2}$ & 0.21 & 0.21 & 0.21 & 0.06 & 0.12 & 0.32 \\
\hline \multirow[t]{2}{*}{$\mathrm{c}^{2}$} & 0.11 & 0.11 & 0.11 & 0.02 & 0.08 & 0.15 \\
\hline & \multicolumn{6}{|c|}{ Survival } \\
\hline$\sigma_{a}^{2}$ & 0.03 & 0.03 & 0.03 & 0.01 & 0.02 & 0.04 \\
\hline$\sigma_{\mathrm{c}}^{2}$ & 0.00 & 0.00 & 0.00 & 0.00 & 0.00 & 0.00 \\
\hline$\sigma_{\mathrm{e}}^{2}$ & 0.06 & 0.06 & 0.06 & 0.00 & 0.05 & 0.07 \\
\hline $\mathrm{h}^{2}$ & 0.32 & 0.33 & 0.33 & 0.07 & 0.22 & 0.44 \\
\hline$c^{2}$ & 0.00 & 0.00 & 0.00 & 0.00 & 0.00 & 0.00 \\
\hline
\end{tabular}

${ }^{(1)}$ Kernel density estimates of the marginal posterior distributions. SD: standard deviation. 
Charo-Karisa et al. (2006) (Table 2 and Figure 1). The increase of the heritabilities for body weight, from tagging to harvest, indicated higher contribution of the additive genetic variance as a proportion of the phenotypic variance. The amount of data used in this study for parameter estimation was limited, but the quantity of pedigreed individuals was comparable to that of other studies. The credible intervals of posterior distributions were, to some extent, a measure of how the limitations influenced results or evidenced whether the parent-offspring genetic ties were strong enough to conserve maximum likelihood properties and to accurately separate genetic and systematic environmental effects. Hence, posterior densities were more precise for describing the state of ignorance about parameters.

Even if a strain has undergone several generations of selection, high additive genetic variances indicate that further improvement can be achieved (Ponzoni et al.,
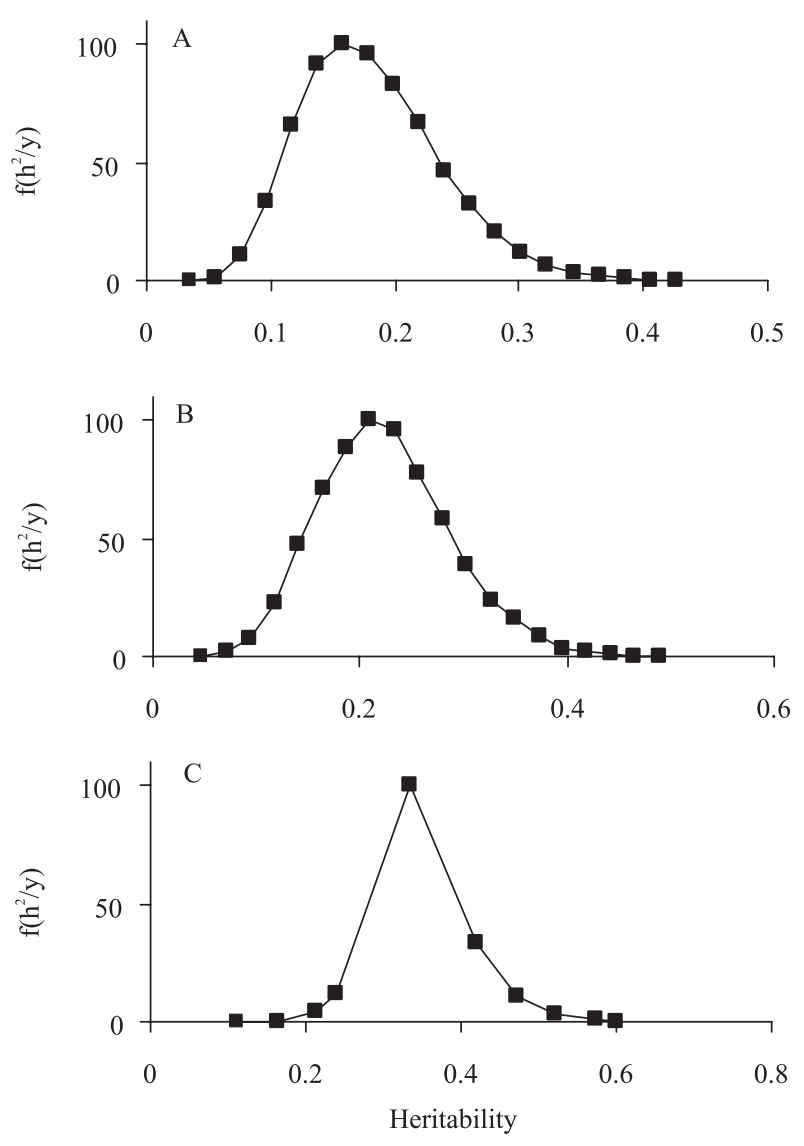

Figure 1. Marginal posterior distributions of heritabilities [f( $\left.\left.\mathrm{h}^{2} / \mathrm{y}\right)\right]$ for: A, tagging weight; $\mathrm{B}$, harvest weight; and $\mathrm{C}$, survival for tilapia farmed in Brazil.
2005). Rutten et al. (2005) found additive genetic variances between 1,481 $\mathrm{g}^{2}$ and 2,778 $\mathrm{g}^{2}$, working with tilapia, with an average body weight at harvest varying from 286.1 to $403.6 \mathrm{~g}$. In comparision to the wide range of genetic resources, the results of additive genetic variances for harvest weight in this study can be considered promising, and indicate the potential for genetic progress under farm conditions in Brazil (Table 2).

Survival was found to be moderately heritable, with posterior heritabilities generally higher than for body weight (Table 2 and Figure 1C). In the few studies carried out for tilapia survival (Charo-Karisa et al., 2006; Rezk et al., 2009), the heritabilities (0.03-0.14) were lower than the estimated in this study. Posterior credible intervals did not include these values.
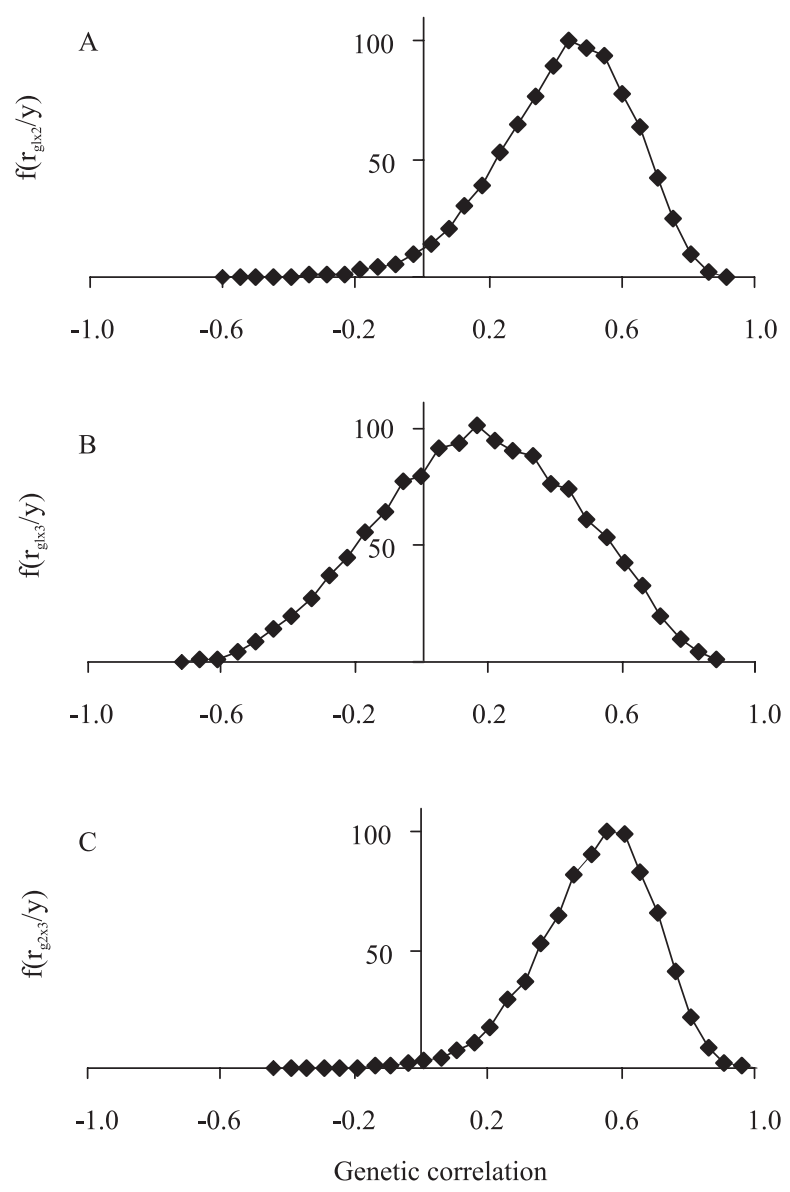

Figure 2. Marginal posterior distributions of genetic correlations $\left[\mathrm{f}\left(\mathrm{r}_{\text {gaxb }} / \mathrm{y}\right)\right]$ between: A, tagging and harvest weight; $\mathrm{B}$, tagging weight and survival; and $\mathrm{C}$, harvest weight and survival for tilapia farmed in Brazil. 
Similar and mainly higher estimates of heritability for survival (0.2-0.74) were found in studies evaluating tilapia in Brackish water (Luan et al., 2008) or under different temperatures (Chiayvareesajja et al., 1999), and rainbow trout exposed to different causative agents of disease (Henryon et al., 2005). However, in these experiments, fish were subjected to challenge. When survival is considered a measure of individual resistance to a specific challenge, greater genetic advance can be reached with a higher challenge, since genetic differences are more easily evidenced (Nieto et al., 2001).

While examining survival across diverse agro-climatic conditions, there may be evidence of robust fish, which are potentially resistant to multiple environmental disturbances, stressors, and mortality factors. This could greatly contribute to increase animal welfare and to the ability to manage animals in a wide range of environments (Vehviläinen et al., 2008). In this study, the experiment design did not evaluate fish subjected to any specific challenge, but it is possible that low temperature during communal rearing could have acted as a challenge factor, contributing to a higher survival rate.

The understanding of the population genetic structure with relative contributions of the genetic and environmental components in determining trait variance is a crucial aspect for fish breeding programs (Ponzoni et al., 2005; Khaw et al., 2008). Estimates of heritability obtained in this study, from low to moderate, suggested strong influence of nonsystematic environmental effects on weight and survival traits (Table 2 and Figure 1).

For harvest weight, the results of heritability imply that the fish phenotypic value is not a sensible predictor of genetic potential. Although mass selection is the most frequently applied strategy in fish, because of its simplicity, it is not efficient, since breeding candidates are selected only based on their own phenotypic performance.

When the pedigree of brood fish is monitored and all availablesourcesofinformationarecombined toestimate the genetic merit of fish, a greater selection response can be achieved and accumulation of inbreeding can also be prevented (Bolivar \& Newkirk, 2002; Ponzoni et al., 2010). This strategy is recommended and may be implemented by the adoption of the best linear unbiased prediction (BLUP) procedure in a framework of mixed model methodology, which allows the simultaneous estimation of breeding values and adjustment for fixed effects.

Survival rate should be included in the breeding objective, as it determines the number of fish available for market and the profit on fish farming. The heritabilities found indicate that it is possible to obtain response to selection (Table 2). However, the genetic architecture of survival differs from conventional traits due to its complex origin. Survival is influenced by underlying component traits, whose expression may vary in time and space. This finding was evidenced by Vehviläinen et al. (2008), who analysed extensive data on survival of rainbow trout, observing that genetic correlations can be even more negative by treating survival as a different trait in different generations and environments.

It is possilble that selection for survival or other correlated traits can lead to maladaptations in certain environments. There must be caution when using survival as a selection criterion, and it is important to monitor this trait throughout the genetic improvement program. At the farm level, improvement of the survival rate can be achieved through the enhancement of environmental factors, such as better management, feeding, diet or water quality.

The maternal common environment effect $\left(c^{2}\right)$, estimated from the hapa variance component, was significant for weight traits, mainly at tagging (Table 2). In this experiment, the rearing environment was kept as uniform as possible in the hapas, but a substantial effect was expected, because of the prolonged period before tagging, while full-sibs were kept together. It is possible that tagging at a later time complicated the estimation of the $\mathrm{c}^{2}$ value for survival, which was not significant.

All results for $\mathrm{c}^{2}$ obtained by Rezk et al. (2009) were over the Bayesian credible interval (Table 2). In Rutten et al. (2005), fish were tagged with around $5 \mathrm{~g}$, but weighed $50 \mathrm{~g}$ at the age of the first measurement, in which a value of 0.21 was found for $\mathrm{c}^{2}$, lower than the obtained in this study, for tagging weight.

As in other studies (Ponzoni et al., 2005; Rutten et al., 2005; Rezk et al., 2009), values of $\mathrm{c}^{2}$ decreased but were still significant at the time of harvest (credible intervals did not include zero). Correcting for this effect is necessary to obtain unbiased estimates of parameters, because of the impact on fish performance. 
The genetic correlations were estimated with high standard deviations and large credible intervals, which indicate considerable uncertainty surrounding the results (Table 3 and Figure 2). The means of posterior distributions suggested a positive genetic relationship among the traits evaluated. This is consistent with the indicated by Gjedrem (2005) and Rezk et al. (2009), whereas Chiayvareesajja et al. (1999) did not find significant correlations between survival and body weight.

Point estimates of the genetic correlation between tagging and harvest weight were higher than the reported by Rezk et al. (2009), but were included in the credible interval (Table 3 ). A longer grow-out period could reduce this correlation; however, because of the wide credible interval, it is not reasonable to use initial weight as a selection criterion for improving body weight in tilapia.

The genetic correlation between tagging weight and survival was not significantly different from zero, since the credible interval spans the zero value (Table 3 ). Credible intervals varied from moderate to high for the genetic correlation between harvest weight and survival, which shows a positive association between these two traits. Therefore, it should be relatively easy to improve harvest weight and survival simultaneously.

Unfortunately, poor precision was achieved for the parameters of genetic correlation, but it is not atypical in tilapia (Table 3). This is often the case in studies involving a small number of full-sib families. Other studies, which examined the genetic control of body weight and survival in tilapia, could not successfuly estimate those correlations (Charo-Karisa et al., 2006; Luan et al., 2008) or estimated the parameter with high imprecision (Rezk et al., 2009).

Henryon et al. (2005) also used a Bayesian approach to estimate survival parameters, but as a measure of fish resistance to diseases across time. Since the association between survival and weight was only indirectly assessed through a longitudinal approach, the authors did not obtain correlation between these traits. Body weight affected resistance to different diseases in different ways, although the relationship remained unclear.

Recent studies (Khaw et al., 2008; Ponzoni et al., 2010) have indicated that the GIFT population is well equipped to continue to respond to selection, which can increase production in developing countries. However, due to the small population size of the GIFT strain (Ponzoni et al., 2010), its introduction in regions with a different climate could lead the population to a lack of capacity to cope with the increase in the genetic load.

The population adapted well to the farming conditions studied, and the additive genetic variances showed great potential for the genetic advancement of this population in Brazil, which is in accordance with the genetic advancement predicted by this study (Table 4).

Table 3. Estimates of genetic correlations ( $\mathrm{r}_{\mathrm{g}}$ ) between pair of traits for tagging weight (1), harvest (2) body weight, and survival rate (3), with $95 \%$ credible intervals in tilapia farmed in Brazil.

\begin{tabular}{lcccccc}
\hline Parameter & Mean & Median & Mode ${ }^{(1)}$ & SD & \multicolumn{2}{c}{ Credible interval (\%) } \\
\cline { 5 - 7 } & & & & 0.20 & 0.04 & 97.5 \\
\hline$r_{\mathrm{g} 1 \times 2}$ & 0.40 & 0.42 & 0.45 & 0.29 & -0.35 & 0.69 \\
$r_{\mathrm{g} 1 \times 3}$ & 0.14 & 0.14 & 0.14 & 0.17 & 0.19 & 0.71 \\
$\mathrm{r}_{\mathrm{g} 2 \times 3}$ & 0.50 & 0.51 & 0.56 &
\end{tabular}

${ }^{(1)}$ Kernel density estimates of the marginal posterior distributions. SD: standard deviation.

Table 4. Estimates of predicted genetic advance for tagging weight, harvest body weight, and survival rate from selection for harvest weight in tilapia farmed in Brazil.

\begin{tabular}{|c|c|c|c|c|c|}
\hline \multirow[t]{2}{*}{ Selected population } & \multirow[t]{2}{*}{ Nsi } & \multirow[t]{2}{*}{ Nsf } & \multicolumn{3}{|c|}{ Predicted genetic gain $(\mathrm{GG} \%)$} \\
\hline & & & Tagging weight & Harvest weight & Survival \\
\hline & \multicolumn{5}{|c|}{ Very best individuals } \\
\hline Male & 60 & 13 & 3.4 & 15.0 & 4.5 \\
\hline \multirow[t]{2}{*}{ Female } & 120 & 14 & 5.2 & 13.8 & 2.1 \\
\hline & \multicolumn{5}{|c|}{ Best by family } \\
\hline Male & 180 & 33 & 2.9 & 7.4 & 3.7 \\
\hline Female & 360 & 33 & 1.8 & 3.9 & 1.2 \\
\hline
\end{tabular}

Nsi, number of selected individuals; Nsf, number of selected families. 
The selection of the best individuals for mating provided highest $\mathrm{GG} \%$, but a small number of families (sires and dams of the previous generation) were represented among the selected individuals (Table 4). To achieve a greater selection response and restrict inbreeding, a common strategy in fish breeding is to select the best families and then the best individuals of these families, keeping back-ups for selected fish. However, because of the small number of families, family selection was impractible in this study, although the selection of individuals from every family is highly recommended. The standardization of the selective breeding technology with the adoption of artificial incubators for each full-sib family will certainly improve the number of successful mating pairs and ensure the long-term sustainability of the genetic improvement program.

From a breeding viewpoint, the estimated genetic parameters provided the necessary background to determine the best selection strategy to be adopted in the genetic improvement program in order to allow the selection response and efficient advancement predicted by this study. The wide genetic variance found for production and survival traits and the maintenance of the genetic variability will assure continuous advances in future selected generations.

\section{Conclusions}

1. The additive genetic variance and low to moderate heritabilitie for production and survival traits confirmed great potential to the genetic progress in the evaluated population.

2. Positive genetic correlations suggest that survival can be indirectly improved by selection for fish weight; however, if mortality factors change, this relationship may not be maintained.

3. The predicted genetic gain was high when selection for harvest weight was performed for fish under different farming conditions in Brazil.

\section{Acknowledgements}

To Conselho Nacional de Desenvolvimento Científico e Tecnológico, for support. To students and staff from the Estação de Aquacultura of the Universidade Estadual de Maringá, for help during the experiments. To WorldFish Center, for providing fish from the GIFT population and to its researchers, for assistance.

\section{References}

ATWOOD, H.L.; TOMASSO, J.R.; WEBB, K.; GATLIN, D.M. Low-temperature tolerance of Nile tilapia, Oreochromis niloticus: effects of environmental and dietary factors. Aquaculture Research, v.34, p.241-251, 2003.

BOLIVAR, R.B.; NEWKIRK, G.F. Response to within family selection for body weight in Nile tilapia (Oreochromis niloticus) using a single-trait animal model. Aquaculture, v.204, p.371-381, 2002.

CHARO-KARISA, H.; KOMEN, H.; REZK, M.A.; PONZONI, R.W.; ARENDONK, J.A.M. van; BOVENHUIS, H. Heritability estimates and response to selection for growth of Nile tilapia (Oreochromis niloticus) in low-input earthen ponds. Aquaculture, v.261, p.479-486, 2006.

CHIAYVAREESAJJA， J.; RØED， K.H.; EKNATH, A.E.; DANTING, J.C.; DE VERA, M.P.; BENTSEN, H.B. Genetic variation in lytic activities of blood serum from Nile tilapia and genetic associations with survival and body weight. Aquaculture, v.175, p.49-62, 1999.

CRESSEY, D. Future fish: the only way to meet the increasing demand for fish is through aquaculture. Nature, v.458, p.398-400, 2009.

EKNATH, A.E.; ACOSTA, B.O. Genetic improvement of farmed tilapias (GIFT) project: final report, march 1988 to december 1997. Makati City: International Center for Living Aquatic Resources Management, 1998.

FOOD AND AGRICULTURE ORGANIZATION OF THE UNITED NATIONS. The state of world fisheries and aquaculture 2008. Rome: FAO, 2009. 18p. Available at: <ftp://ftp.fao.org/ docrep/fao/011/i0250e/i0250e00.pdf>. Accessed on: 23 Oct. 2010.

GILMOUR, A.R.; GOGEL, B.J.; CULLIS, B.R.; WELHAM, S.J.; THOMPSON, R. ASReml user guide. Release 1.0. Hemel Hempstead: VSN International, 2002.

GJEDREM, T. Selection and breeding programs in aquaculture. The Netherlands: Springer, 2005. 364p.

HEIDELBERGER, P.; WELCH, P.D. Simulation run length control in the presence of an initial transient. Operations Research, v.31, p.1109-1114, 1983.

HENRYON, M.; BERG, P.; OLESEN, N.J.; KJAER, T.E.; SLIERENDRECHT, W.J.; JOKUMSEN, A.; LUND, I. Selective breeding provides an approach to increase resistance of rainbow trout (Onchorhynchus mykiss) to the diseases, enteric redmouth disease, rainbow trout fry syndrome, and viral haemorrhagic septicaemia. Aquaculture, v.250, p.621-636, 2005.

KHAW, H.L.; PONZONI, R.W.; DANTING, M.J.C. Estimation of genetic change in the GIFT strain of Nile tilapia (Oreochromis niloticus) by comparing contemporary progeny produced by males born in 1991 or in 2003. Aquaculture, v.275, p.64-69, 2008.

LUAN, T.D.; OLESEN, I.; ØDEGÅRD, J.; KOLSTAD, K.; DAN, N.C. Genotype by environment interaction for harvest body weight and survival of nile tilapia (Oreochromis niloticus) in brackish and fresh water ponds. In: INTERNATIONAL SYMPOSIUM ON 
TILAPIA IN AQUACULTURE, 8., 2008, Cairo. Proceedings. Cairo: CICC, 2008. v.1, p.231-240.

MORA, F.; GONÇALVES-VIDIGAL, M.C.; SANTOS, A.I. Bayesian analysis of the genetic control of survival in F3 families of common bean. Chilean Journal of Agricultural Research, v.68, p.334-341, 2008.

NIETO, L.M.; MARTINS, E.N.; MACEDO, F.A.F. de; DOS SANTOS, A.I. Estimación de componentes varianza para la resiliencia genética a endoparásitos en ovinos. Revista de Ciencia y Tecnología, v.4a, p.60-64, 2001.

PONZONI, R.W.; HAMZAH, A.; TAN, S.; KAMARUZZAMAN, $\mathrm{N}$. Genetic parameters and response to selection for live weight in the GIFT strain of Nile tilapia (Oreochromis niloticus). Aquaculture, v.247, p203-210, 2005.

PONZONI, R.W.; KHAW, H.L.; NGUYEN, H.N.; HAMZAH, A. Inbreeding and effective population size in the Malaysian nucleus of the GIFT strain of Nile tilapia (Oreochromis niloticus). Aquaculture, v.302, p.42-48, 2010.

PONZONI, R.W.; NGUYEN, H.N.; KHAW, H.L.; KAMARUZZAMAN, N.; HAMZAH, A.; BAKAR, K.R.A.; YEE, H.Y. Genetic improvement of Nile tilapia (Oreochromis niloticus) -present and future. In: INTERNATIONAL SYMPOSIUM ON TILAPIA IN AQUACUlTURE, 8., 2008, Cairo. Proceedings. Cairo: CICC, 2008. v.1, p.33-52.

R DEVELOPMENT CORE TEAM. R: A language and environment for statistical computing. Vienna: R Foundation for Statistical Computing, 2007. Available at: <http://www.R-project. org >. Accessed on: 10 June 2009.

REZK, M.A.; PONZONI, R.W.; KHAW, H.L.; KAMEL, E.; DAWOOD, T.; REZK, G.J. Selective breeding for increased body weight in a synthetic breed of Egyptian Nile tilapia, Oreochromis niloticus: response to selection and genetic parameters. Aquaculture, v.293, p.187-194, 2009.

RUTTEN, M.J.M.; KOMEN, H.; BOVENHUIS, H. Longitudinal genetic analysis of Nile tilapia (Oreochromis niloticus L.) body weight using a random regression model. Aquaculture, v.246, p.101-113, 2005.

SAS INSTITUTE. SAS/STAT user's guide. Version 9.1.3. Cary: SAS Institute, 2005.

SPIEGELHALTER, D.; THOMAS, A.; BEST, N.; LUNN, D. WinBUGS user manual. Version 1.4. Cambridge: MRC Biostatistics Unit, 2003.

VAN TASSELL, C.P.; VAN VLECK, L.D.; GREGORY, K.E. Bayesian analysis of twinning and ovulation rates using a multiple-trait threshold model and Gibbs sampling. Journal of Animal Science, v.76, p.2048-2061, 1998.

VEHVILÄINEN, H.; KAUSE, A.; QUINTON, C.; KOSKINEN, H.; PAANANEN, T. Survival of the currently fittest: genetics of rainbow trout survival across time and space. Genetics, v.180, p.507-516, 2008.

WAGNER, P.M.; RIBEIRO, R.P.; MOREIRA, H.L.M.; VARGAS, L.; POVH, J.A. Avaliação do desempenho produtivo de linhagens de tilápia do Nilo (Oreochromis niloticus) em diferentes fases de criação. Acta Scientiarum: Animal Sciences, v.26, p.187-196, 2004.

WRIGHT, D.R.; STERN, H.S.; BERGER, P.J. Comparing traditional and Bayesian analyses of selection experiments in animal breeding. Journal of Agricultural, Biological, and Environmental Statistics, v.5, p.240-256, 2000.

YI, Y.; LIN, C.K. Effects of biomass of caged Nile tilapia (Oreochromis niloticus) and aeration on the growth and yields in an integrated cage-cum-pond system. Aquaculture, v.195, p.253-267, 2001.

Received on August 24, 2010 and accepted on December 3, 2010 